\title{
Determination of ERP Readiness Assessment using Agile Parameters: A Case Study
}

\author{
Santo Fernandi Wijaya*,1, Harjanto Prabowo ${ }^{2}$, Ford Lumban Gaol ${ }^{3}$, Meyliana ${ }^{1}$ \\ ${ }^{1}$ Information Systems Department, School of Information System, Bina Nusantara University, Jakarta, 11480, Indonesia \\ ${ }^{2}$ Management Department, BINUS Business School Undergraduate Program, Bina Nusantara University, Jakarta, 11480, Indonesia \\ ${ }^{3}$ Computer Science Department, BINUS Graduate Program, Bina Nusantara University, Jakarta, 11480, Indonesia
}

\author{
A R T I C L E IN F O \\ Article history: \\ Received: 02 July, 2020 \\ Accepted: 05 August, 2020 \\ Online: 28 August, 2020
}

Keywords:

Agile ERP

Implement

Readiness assessment

Textile industry

\begin{abstract}
A B S T R A C T
At present, in the era of digitization the organizations need Enterprise Resource Planning (ERP) systems to have the ability adapt to changes with rapid response in order to increase the competitive advantage. The fact, many companies have failed to implement ERP which is proven to be not go live on time, so that the implementation value is to be very expensive. For this reason, it is important to consider other methods that can reduce failures in implementing ERP that are reviewed from the perspective of readiness assessment. Based on previous research, there are some challenging on the ERP readiness assessment. We also found that some areas on the ERP readiness that still not explore more serious such as ERP and agile method. Therefore, based on the challenging and open are on the ERP readiness, we will explore more development the framework of ERP readiness assessment using agile parameters to help the industry. The purpose of this research is to identify gaps and propose improvements which are the weaknesses in order to improve performance of the organization. The result of this research is developing the framework using an agile parameter for determination of the ERP readiness assessment with a case study in the textile industry in Indonesia. Hopefully, this research has contribution as a measurement tool for assessing the organizational readiness in order to increase agility in the industry. This research methodology uses the combination of qualitative and quantitative research methods using the NVivo software as a result of FGD data processing and using the Technique for Order Preference by Similarity (TOPSIS) for validation and verification tests.
\end{abstract}

\section{Introduction}

Now, more than ever before, technology must provide satisfying services and ensure that everyone can get it the information they need quickly and precisely for the decision making. Thus, technology is changing the way people work towards digitization. Information systems could manage, disseminate, and produce the information that accurate, real-time, and informative in order to the provide attractive services to managerial levels for the decision making. ERP is an integrated information system that allows people to monitor business activities. ERP implementation for the industry is an absolute necessity in improving effective, efficient, and improving organizational performance. With the use of ERP, it allows

*Corresponding Author Santo Fernandi Wijaya, Email: santofw@binus.ac.id management of the organization to apply the work method with the paperless principle in which business activities can be monitored online and real-time, so that it can be obtained easily obtain various information quickly, accurately and informally without knowing the time and place. Thus, the application of ERP is very helpful managerial level in making decisions appropriately and quickly. This is a reason for organization to increase technology support in managing business activities. Therefore, the use of ERP systems is fundamental of the organizations in order to improve the performance and have a competitive advantage. However, the reality in implement ERP for the industry tends to experience a failure risk level of up to $40 \%$ [1]. Based on the previous research that the critical factors which cause failure in ERP implementation is the readiness assessment 
[2]. Thus, the adopt agile method in ERP readiness assessment is to be considered. The principle of agile methods that emphasize the collaboration and communication work and responding to changes [3]. For this reason, it is the important to assess the organizational readiness using agile parameters. The agile parameters for ERP can follow changes and increase business value. Even so, suggesting whether the agile method is suitable for ERP implementation in the industry, the authors will carry out further research. This research aims to solve the complexity in ERP implementation by focusing on evaluating ERP readiness using agile parameters to answer the research questions as follows:

a. Whether the agile method is suitable for ERP implementation in the industry?

b. What kind of the framework is proposed for ERP readiness assessment in the industry?

\section{Literature Review}

\subsection{ERP readiness assessment}

The dimensions and factors of agile method are organization, processes, people, and project [4]. The dimensions and factors of agile are shown in the Table 1.

Table 1: Dimensions and factors of agile [4]

\begin{tabular}{|c|c|l|}
\hline Dimensions & \multicolumn{2}{|c|}{ Agile factors } \\
\hline \multirow{4}{*}{ Organization } & 1 & Collaborative work environment \\
\cline { 2 - 3 } & 2 & Top management support - involvement \\
\cline { 2 - 3 } & 3 & Adaptive view toward change \\
\cline { 2 - 3 } & 4 & Cooperative horizontal business culture \\
\cline { 2 - 3 } & 5 & People oriented culture \\
\hline \multirow{5}{*}{ Process } & 6 & Adaptive/iterative requirements management \\
\cline { 2 - 3 } & 7 & Early delivery of important features \\
\cline { 2 - 3 } & 8 & Regular and frequent communication \\
\cline { 2 - 3 } & 9 & Test driven environment \\
\cline { 2 - 3 } & 10 & Co-location of staff \& stakeholders \\
\hline \multirow{5}{*}{ People } & 11 & Adaptive leadership style \\
\cline { 2 - 3 } & 12 & Self-organizing teams \\
\cline { 2 - 3 } & 13 & Close team customer relationship \\
\hline \multirow{5}{*}{ Project } & 14 & Rapid/early delivery of value \\
\cline { 2 - 3 } & 15 & Emergent requirements \\
\cline { 2 - 3 } & 16 & Fluid project schedule \\
\cline { 2 - 3 } & 17 & Customer involvement \\
\cline { 2 - 3 } & 18 & Continuous \& incremental business value \\
\hline
\end{tabular}

The parameters of an agile method are focusing on adaptive and iterative, business needs, on time, collaborating work environment, accountability, responsiveness $[5,6]$. The authors analyze and compares the framework of previous research from survey literature by comparing the following references, research focus, identification factors, identify the main components as measurement tools, validation methods, and model evaluations. The comparison framework of the classification models for ERP readiness assessment is shown in the Table 2.

Considering the result analyze of previous research which little research provides about the framework of agile ERP readiness assessment in order to increasing the organization agility. Thus, the authors propose the development of a framework for the ERP readiness assessment using agile parameters to find out how effective the framework can reduce ERP complexity. The goal of the readiness assessment is to identify gaps and propose improvements that are weaknesses in order for increasing the organization performance.

Table 2: Comparison framework of the classification models for ERP readiness assessment (source: Survey Literature)

\begin{tabular}{|c|c|c|c|c|c|}
\hline $\begin{array}{l}\mathrm{N} \\
\mathrm{o}\end{array}$ & $\begin{array}{l}\text { Research } \\
\text { focus }\end{array}$ & $\begin{array}{l}\text { Compo } \\
\text { nents }\end{array}$ & $\begin{array}{l}\text { Measurement } \\
\text { tool }\end{array}$ & $\begin{array}{l}\text { Method } \\
\text { used }\end{array}$ & $\begin{array}{l}\text { ID } \\
\text { Paper }\end{array}$ \\
\hline 1 & $\begin{array}{l}\text { Develop } \\
\text { ment of } \\
\text { assessment } \\
\text { tool for ERP } \\
\text { readiness }\end{array}$ & $\begin{array}{c}\text { Project } \\
\text { Manage } \\
\text { ment, } \\
\text { Organiza } \\
\text { tional, } \\
\text { Change } \\
\text { manage } \\
\text { ment } \\
\end{array}$ & $\begin{array}{l}\text { Framework } \\
\text { hierarchy of } \\
\text { Critical } \\
\text { Factors for } \\
\text { ERP } \\
\text { Readiness }\end{array}$ & $\begin{array}{l}\text { AHP \& } \\
\text { FANP }\end{array}$ & {$[2]$} \\
\hline 2 & $\begin{array}{l}\text { Developing } \\
\text { of organiza } \\
\text { tional } \\
\text { readiness } \\
\text { assessment } \\
\text { model }\end{array}$ & $\begin{array}{l}\text { Organiza } \\
\text { tional }\end{array}$ & $\begin{array}{c}\text { Data } \\
\text { gathering \& } \\
\text { analysing for } \\
\text { organizational } \\
\text { readiness }\end{array}$ & $\begin{array}{l}\text { FCM, } \\
\text { DEMATEL } \\
\text { Cluster }\end{array}$ & {$[5]$} \\
\hline 3 & $\begin{array}{l}\text { Develop } \\
\text { ment of } \\
\text { assessment } \\
\text { tool }\end{array}$ & $\begin{array}{l}\text { Technowa } \\
\text { re, Human } \\
\text { ware, } \\
\text { Infoware, } \\
\text { Orgaware }\end{array}$ & $\begin{array}{l}\text { Critical } \\
\text { Factors for } \\
\text { ERP } \\
\text { Readiness }\end{array}$ & TOPSIS & [7] \\
\hline 4 & $\begin{array}{l}\text { Develop } \\
\text { ment of } \\
\text { framework } \\
\text { for ERP } \\
\text { assessing } \\
\text { readiness }\end{array}$ & $\begin{array}{l}\text { Organiza } \\
\text { tional }\end{array}$ & $\begin{array}{c}\text { Scale } \\
\text { measurement } \\
\text { questionaire }\end{array}$ & CFA, SEM & {$[8]$} \\
\hline 5 & $\begin{array}{l}\text { Develop } \\
\text { ment of ERP } \\
\text { readiness } \\
\text { assessment } \\
\text { model }\end{array}$ & $\begin{array}{c}\text { Top } \\
\text { manage } \\
\text { ment, } \\
\text { Project } \\
\text { manage } \\
\text { ment, } \\
\text { People, } \\
\text { Change } \\
\text { manage } \\
\text { ment, } \\
\text { Tehnical } \\
\text { require } \\
\text { ment } \\
\end{array}$ & $\begin{array}{c}\text { Comparation } \\
\text { Survey } \\
\text { Literature \& } \\
\text { Case study }\end{array}$ & $\begin{array}{l}\text { AHP, } \\
\text { MOORA \& } \\
\text { TOPSIS }\end{array}$ & [9] \\
\hline 6 & $\begin{array}{l}\text { Develop } \\
\text { ment of } \\
\text { framework } \\
\text { for ERP } \\
\text { readiness }\end{array}$ & $\begin{array}{c}\text { Organiza } \\
\text { tional } \\
\text { context, } \\
\text { Business } \\
\text { processes, } \\
\text { Perception } \\
\text { of ERP, } \\
\text { External }\end{array}$ & $\begin{array}{c}\text { Data synthesis } \\
\text { tool }\end{array}$ & $\begin{array}{c}\text { SPSS } \\
\text { software } \\
\text { Cluster } \\
\text { Analysis }\end{array}$ & [10] \\
\hline 7 & $\begin{array}{l}\text { Framework } \\
\text { for ERP } \\
\text { assessing } \\
\text { readiness }\end{array}$ & $\begin{array}{l}\text { Organizati } \\
\text { onal }\end{array}$ & $\begin{array}{c}\text { Rating 9S } \\
\text { model based } \\
\text { by agility } \\
\text { factors criteria }\end{array}$ & $\begin{array}{c}\text { TOPSIS, } \\
\text { Fuzzy AHP }\end{array}$ & [11] \\
\hline
\end{tabular}

\subsection{ERP readiness factors}

Adopting the Literature Review Prisma [12], researchers conducted a search through database searching with the ERP readiness factor. The results of the filtering of the article after reading the abstract and the introduction of the selected articles, then the authors makes a mapping and comparison which is a factor of ERP readiness. From these factors, the authors define 
and meta analyzes of the factors based on the writing in the article. Then the authors categories the ERP readiness factors into four main dimensions, namely processes, people, organizational, and technology. The four main dimensions are based on the Leavitt Diamond Model [13]. The main dimensions of the Leavitt Diamond Model consist of structure, technology, people, and tasks, with the following explanation:

- Structure approach. Is an effort that is applied to improve organizational behavior through increased task performance, such as changes in communication systems, authority systems, workflow systems, structural changes. This is categorized in the organizational.

- Technology approach. Respond to technological trends to support significant organizational changes, and problem solving such as work measurement techniques.

- Task approach. Refers to the process of producing goods or services, which are categorized as processes.

- People approach. Changing the behavior of people in organizations, and changing human behavior that will cause changes to complete tasks, achieve performance, and meet the qualifications criteria of people as needed

Based on the literature survey, the authors do a mapping of the ERP readiness factors that affect each of these components. The mapping results show that there are 18 factors that can be considered for these 4 components. The result mapping for the comparison of ERP readiness factors is shown in the Table 3.

Table 3: Comparison of ERP readiness factors (source: Survey literature)

\begin{tabular}{|c|c|c|c|}
\hline 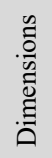 & No & Factors & ID Paper \\
\hline \multirow{3}{*}{ 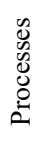 } & 1 & Business process change & {$[14]$} \\
\hline & 2 & Process business integration & {$[14,15,16]$} \\
\hline & 3 & Development of business & {$[17,14,18,19]$} \\
\hline \multirow{3}{*}{$\begin{array}{l}\frac{0}{0} \\
\text { مे } \\
0\end{array}$} & 4 & Management support & {$[14,20,21]$} \\
\hline & 5 & Skill project team & {$[4,9]$} \\
\hline & 6 & Train and education & {$[13,20]$} \\
\hline \multirow{7}{*}{ 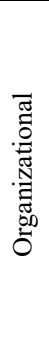 } & 7 & Organization agile & {$[1,4,9,18,20,21]$} \\
\hline & 8 & Communication \& collaboration & {$[18,22]$} \\
\hline & 9 & Project management & {$[16,18,19,22,23]$} \\
\hline & 10 & Industry characteristics & [24] \\
\hline & 11 & Change management & {$[14,18,22,25]$} \\
\hline & 12 & Strategy planning & {$[15,18,23,24]$} \\
\hline & 13 & Organization culture & {$[14,22]$} \\
\hline \multirow{5}{*}{ 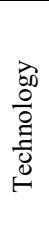 } & 14 & ERP implementation & {$[14,15,20,22,[3]$} \\
\hline & 15 & Agile method & {$[14,17,20,25]$} \\
\hline & 16 & Technological & {$[14]$} \\
\hline & 17 & System Integration & {$[14,24]$} \\
\hline & 18 & ERP system & {$[14,20,22,23]$} \\
\hline
\end{tabular}

\subsection{Agile for ERP}

The agile factors are flexibility, speed, responsiveness, competency, agility, and integration [25]. The mapping result for definition of agile factors depicted in the Table 4.

Table 4: Definition of Agile factors [source: survey literature]

\begin{tabular}{|c|c|c|}
\hline Factors & Definition & ID Paper \\
\hline Flexibility & $\begin{array}{l}\text { Ability to process different products and } \\
\text { achieve different objectives with the same } \\
\text { facilities }\end{array}$ & $\begin{array}{l}{[17,20,} \\
26]\end{array}$ \\
\hline Speed & $\begin{array}{l}\text { Ability to carry out tasks and operations in } \\
\text { shortest possible time }\end{array}$ & $\begin{array}{c}{[17,20,} \\
26]\end{array}$ \\
\hline $\begin{array}{l}\text { Responsive } \\
\text { ness }\end{array}$ & $\begin{array}{l}\text { Ability to identify changes and respond } \\
\text { quickly }\end{array}$ & {$[20,26]$} \\
\hline Competency & $\begin{array}{l}\text { Extensive set of abilities that provide a basis } \\
\text { for productivity, efficiency and effectiveness } \\
\text { of a company's activities }\end{array}$ & $\begin{array}{l}{[17,20,} \\
26]\end{array}$ \\
\hline $\begin{array}{l}\text { Account } \\
\text { ability }\end{array}$ & $\begin{array}{l}\text { Proves to be the most important catalytic } \\
\text { agent in guiding the drivers of organization } \\
\text { agility }\end{array}$ & {$[17,20]$} \\
\hline Integration & $\begin{array}{l}\text { Relations between the individual system } \\
\text { components, easy \& effortless flow of the } \\
\text { materials, information \& communication } \\
\text { between the system components, } \\
\text { organizational structures, people, \& } \\
\text { technology }\end{array}$ & [20] \\
\hline
\end{tabular}

The collaborative \& iterative function in the agile method can adapt to changes, simplify processes, move quickly, and work teams. [27]. Besides that, Agile approaches to supply all effectively sequence, quick response, \& manage the manufacturing process in order to reduce lead times [27]. Therefore, the agile for ERP can be considered for analysis and carried out further research as a way for reducing the complexity of ERP implementation. Iterative and collaborative of each stage of implementation, thereby making project work more effective and efficient. Based on the explanation of the definition of agile factors, it can be considered to help the stages of the processes for implement ERP for achieving the organization agility.

\subsection{ERP in textile industry}

One of the important roles of ERP for the industry is system integration, which make it possible to reduce repetition of work, thereby increasing work efficiency. This also applies to the textile industry. Supply chain issues in textile activities are a customization of system, typical product, marketplace demand, product variety, product life cycle, customer drivers, profit margins, dominant costs, stockout penalties, information enrichment, and forecasting mechanism [27]. Effective change management scheme including enough staff training is necessary, and clear business vision and understand the scope of installation complexity [28]. ERP for textiles to be able to control the quality of raw materials better, so as to produce finished products according to customer demand, easily obtain various information in real-time, precise, and fast, including in the financial reporting process $[6,20,28]$. The essence of agile methods is collaborative and effective communication, adaptation $\&$ iterative response to 
change, to overcome the complexity of ERP [29]. The main process in the textile process is routine sequential production processes and each process requires strict control, especially in fabric processing to produce finished fabrics. This is to increase efficiency in the process of textile production. It really requires the role of ERP to monitoring production activities automatically and paperless, so that it can improve the way work more effectively and efficiently.

\section{Methodology}

\subsection{Research Methodology}

This research methodology uses NVivo to analyze qualitative data processing by using the Focus Group Discussion (FGD) method and TOPSIS method is used in order to analyze and rank the weight of each criterion. TOPSIS is a multi-criteria decisionmaking method. TOPSIS determines the ideal solution and the negative-ideal solution, selects the alternative with the shortest distance from the ideal solution and the farthest distance from the negative-ideal solution as the best alternative [29]. FGD is one method for conducting interviews with participating industry experts and professionals, so that they can obtain information and feedback based on their experience and knowledge. TOPSIS method can determine the ranking of factors of each criterion. The results of Nvivo and TOPSIS data processing are expected to better understand the results of data analysis for the answer of the research questions.

TOPSIS is a decision-making method for ranking and prioritizing Multi Criteria Decision Making (MCDM). MCDM was first introduced by [29]. TOPSIS aims to rank using the principle that the chosen alternative has the shortest distance from the positive ideal solution and the farthest distance from the negative ideal solution from a geometric point of view by using the distance between two points to determine the relative proximity of an alternative to the optimal solution. The positive ideal solution is defined as the sum of all the best values that can be achieved by each attribute, while the negative-ideal solution consists of all the worst values achieved for each attribute. The stages of weighting the TOPSIS method are as follows [29]:

1. Building a normalized weighted matrix using the following formula:

$$
Y_{i j}=\frac{X_{i j}}{\sqrt{\sum_{i=1}^{m} X^{2}}}
$$

2. Building a weighted normalized matrix by multiplying the normalized matrix with the weighting value of entropy weighting, with the normalization formula for the weighting matrix $\mathrm{v}$ as follows:

$$
\mathrm{V}=\left[\begin{array}{c}
V_{11} V_{12} \ldots . V_{1 n} \\
V_{21} V_{22} \ldots . V_{2 n} \\
V_{m 1} V_{m 2} \ldots . V_{m n}
\end{array}\right]=\left[\begin{array}{l}
W_{1 r 11} W_{2 r 12} \ldots W_{n r 1 n} \\
W_{1 r 21} W_{2 r 22} \ldots W_{n r 1 n} \\
W_{1 r m 1} W_{2 r m 2} \ldots W_{n r m n}
\end{array}\right]
$$

3. Determine the matrix for positive and negative ideal solutions. The positive ideal solution is denoted by $\mathrm{A}+$, while the negative ideal solution is denoted by A-. With the following formula:

$$
\begin{aligned}
A^{*} & \left.=\left\{\left[\max _{i} V_{i j} \mid j \in J\right],\left[\min _{i} V_{i j} \mid j \in J^{1}\right]\right\} 1=1,2, \ldots . m\right\} \\
& =\left\{V_{1}^{*}, V_{2}^{*} \ldots \ldots V_{j}^{*} \ldots . . V_{n}^{*}\right\} \\
A^{-} & \left.=\left\{\left[\min _{i} V_{i j} \mid j \in J\right],\left[\max _{i} V_{i j} \mid j \in J^{1}\right]\right\} i=1,2, \ldots m\right\} \\
& =\left\{V_{1}^{-} V_{2,}^{-} \ldots \ldots V_{j}^{*} \ldots . . V_{n}^{*}\right\}
\end{aligned}
$$

4. Calculate the distance between the value of each alternative solution with a positive ideal solution matrix and a negative ideal solution matrix. By using the following formula:

$$
\begin{aligned}
& S_{i}^{*}=\sqrt{\sum_{j=1}^{n}\left(V_{i j}-V_{i}^{*}\right)^{2},} \quad i=1,2, \ldots m \\
& S_{i}^{-}=\sqrt{\sum_{j=1}^{n}\left(V_{i j}-V_{i}^{-}\right)^{2},} \quad i=1,2, \ldots m
\end{aligned}
$$

5. Calculating the preference value to an alternative ideal solution, with the following formula:

$$
C_{i}^{*}=\frac{S_{i}^{-}}{S_{i}^{*}+S_{i}^{-}}
$$

6. Ranking the value of $\mathrm{Ci}+$. The best solution is to have the shortest distance to the ideal solution and the farthest distance to the ideal negative solution.

\subsection{Data Collection}

The authors conducted interviews with respondents with the following criteria such as the respondents understanding business processes of the textile industry in Indonesia, the respondents have managerial positions, and understand the process business of ERP Systems. The authors also distribute the questionnaires to users in the industry as validation and further testing. It is hoped that the results of FGD and Questionnaire process will get meaningful feedback and comments and provide solutions to the problems of this research. The characteristic of respondents is shown in the Table 5.

Table 5: Respondents characteristic

\begin{tabular}{|l|r|r|r|r|}
\hline \multirow{2}{*}{ Respondent profiles } & \multicolumn{2}{|c|}{ FGD } & \multicolumn{2}{|c|}{ Questionnaire } \\
\cline { 2 - 5 } & $\begin{array}{r}\text { Frequen } \\
\text { cy }\end{array}$ & $\%$ & Frequency & $\%$ \\
\cline { 2 - 5 } Gender & & & & \\
Male & 11 & $85 \%$ & 69 & $70 \%$ \\
Female & 2 & $15 \%$ & 29 & $30 \%$ \\
Age & 5 & $38 \%$ & 50 & $51 \%$ \\
$20-30$ & 3 & $23 \%$ & 36 & $37 \%$ \\
$31-40$ & 4 & $31 \%$ & 11 & $11 \%$ \\
$41-50$ & 1 & $8 \%$ & 1 & $1 \%$ \\
$>51$ & & & & \\
\end{tabular}




\begin{tabular}{|c|c|c|c|c|}
\hline \multicolumn{5}{|l|}{ Educational Level } \\
\hline Diploma & 0 & $0 \%$ & 31 & $32 \%$ \\
\hline strata-1 & 7 & $54 \%$ & 51 & $52 \%$ \\
\hline strata-2 & 6 & $46 \%$ & 16 & $16 \%$ \\
\hline \multicolumn{5}{|l|}{ Tenure } \\
\hline $1-2$ years & 0 & $0 \%$ & 12 & $12 \%$ \\
\hline $2-3$ years & 0 & $0 \%$ & 6 & $6 \%$ \\
\hline $4-5$ years & 0 & $0 \%$ & 0 & $0 \%$ \\
\hline$>5$ years & 13 & $100 \%$ & 26 & $27 \%$ \\
\hline \multicolumn{5}{|l|}{$\begin{array}{l}\text { Background of } \\
\text { education }\end{array}$} \\
\hline IT / IS & 13 & $100 \%$ & 55 & $56 \%$ \\
\hline \multicolumn{5}{|l|}{ Finance/Accountin } \\
\hline g & 0 & $0 \%$ & 28 & $29 \%$ \\
\hline Marketing & 0 & $0 \%$ & 15 & $15 \%$ \\
\hline \multicolumn{5}{|l|}{ Role of respondents } \\
\hline Staff & 0 & $0 \%$ & 47 & $48 \%$ \\
\hline Manager/General & & & & \\
\hline Manager & 10 & $77 \%$ & 41 & $42 \%$ \\
\hline Director & 3 & $23 \%$ & 10 & $10 \%$ \\
\hline \multicolumn{5}{|l|}{ Industry type } \\
\hline Industry-Other & 0 & $0 \%$ & 14 & $14 \%$ \\
\hline Industry-Textile & 10 & $77 \%$ & 72 & $73 \%$ \\
\hline IT Consultant & 3 & $23 \%$ & 12 & $12 \%$ \\
\hline
\end{tabular}

\subsection{Data Analysis}

The Data processing this research begins with the data analysis from the node that to identify problems in dimensions and provide the description based on the list of FGD questionnaires. A list of questionnaires for FGD is shown in Table 6.

Table 6: List of questionnaires for Focus Group Discussion

\begin{tabular}{|c|c|}
\hline No & Questionnaire for Focus Group Discussion \\
\hline 1 & $\begin{array}{l}\text { To improve the performance of textile companies, strategies are } \\
\text { needed. One strategy is the use of an ERP system. What do you think? }\end{array}$ \\
\hline 2 & $\begin{array}{l}\text { ERP implementation is complex system. In your experience, what } \\
\text { critical factor causes the successful implementation of ERP for the } \\
\text { industry }\end{array}$ \\
\hline 3 & $\begin{array}{l}\text { ERP projects are usually coordinated by the IT team. Actually, the } \\
\text { ERP project is not an IT project. What do you think of the ERP project } \\
\text { statement as a project management? }\end{array}$ \\
\hline 4 & $\begin{array}{l}\text { Before deciding on ERP implementation, it is necessary to consider } \\
\text { readiness factors such as organizational readiness, project } \\
\text { management readiness, \& change management readiness. Which } \\
\text { factors are dominant in achieving implementation ERP success? }\end{array}$ \\
\hline 5 & $\begin{array}{l}\text { Organizational agility is a critical factor that determines effectiveness } \\
\text { in implementing ERP. The following are organizational readiness } \\
\text { factors, namely: Project management, Training \& education, Business } \\
\text { Process Reengineering, System Integration. In your experience, which } \\
\text { are the most dominant factors of organizational readiness to support } \\
\text { the success of ERP implementation? }\end{array}$ \\
\hline 6 & $\begin{array}{l}\text { The following are the project management sub-factors, namely having } \\
\text { a project management plan, having a formal project team, holding } \\
\text { project status meetings regularly, setting realistic time targets, } \\
\text { defining the scope of the project in detail, conducting effective } \\
\text { communication \& strict supervision of implementation schedule \& } \\
\text { costs. In your opinion, which are the dominant factors of project } \\
\text { management factors that influence the success of ERP } \\
\text { implementation? }\end{array}$ \\
\hline 7 & $\begin{array}{l}\text { The following are the training and education sub-factors, namely } \\
\text { Training as needed in sufficient detail, Training substantially to } \\
\text { increase the level of user understanding, Giving confidence to users } \\
\text { about how to work using the new system, Training is handled by } \\
\text { knowledgeable \& competent trainers according to characteristics } \\
\text { industry. In your opinion, which are the dominant factors of project } \\
\text { management factors that influence the success of ERP } \\
\text { implementation? }\end{array}$ \\
\hline
\end{tabular}

\begin{tabular}{|c|c|}
\hline 8 & $\begin{array}{l}\text { The following are the Business Process Reengineering (BPR) sub- } \\
\text { factors in ERP implementation, namely: Redesigning business } \\
\text { processes before configuring ERP, Standardizing current business } \\
\text { processes, Having sufficient experience in running business processes } \\
\text { from integrated systems, Organizations running computerized systems } \\
\text { with good infrastructure, organizations that have a culture of sharing } \\
\text { information, organizations that have adequate financial resources. In } \\
\text { your opinion, which is the dominant factor of the BPR factor that } \\
\text { affects the success of ERP implementation? }\end{array}$ \\
\hline 9 & $\begin{array}{l}\text { The following are sub-factors of System Integration factors in ERP } \\
\text { implementation, namely: Organizations that integrate the way ERP } \\
\text { works in supporting operations become more effective, Organizations } \\
\text { that are able to integrate ERP with other information systems in the } \\
\text { organization. In your opinion, which are the dominant factors of the } \\
\text { Integration System factor that can influence the success of ERP } \\
\text { implementation? }\end{array}$ \\
\hline 10 & $\begin{array}{l}\text { One of the success factors of ERP implementation is the } \\
\text { implementation methodology. In an effort to reduce the failure of ERP } \\
\text { implementation, it is necessary to consider the agile methodology of } \\
\text { ERP implementation. The agile methodology has effective feedback } \\
\text { characteristics in each iteration \& focuses on system integration. What } \\
\text { do you think about developing an agile model as an alternative to } \\
\text { improving the quality of ERP implementation for an industry? }\end{array}$ \\
\hline 11 & $\begin{array}{l}\text { Management support undertakes a change management process in an } \\
\text { effort to overcome the complexity of project management. What is } \\
\text { your opinion, what is the role of management support in the process of } \\
\text { change management in overcoming the complexity of ERP project } \\
\text { management? }\end{array}$ \\
\hline 12 & $\begin{array}{l}\text { Reducing the risk of failure of ERP implementation for the industry, it } \\
\text { is necessary to develop the Agile ERP method by emphasizing the } \\
\text { incremental \& iterative process in implementing ERP for the industry. } \\
\text { What do you think of the proposal to develop an ERP agile method in } \\
\text { ERP implementation for an industry? }\end{array}$ \\
\hline
\end{tabular}

In conducting interviews, the authors record the interview activities as evidence and for further data processing. then the recording will be transcribed in Microsoft word. Then the authors do data processing using the NVivo application. Based on the factors are identified from the results of data processing, the authors make comparisons with factors from the results of literature studies. After that, the authors build a hierarchy of research models.

Similarly, for a list of questionnaire statements distributed to users for further data management is shown in Table 7.

Table 7: List questionnaire statement

\begin{tabular}{|c|l|l|}
\hline $\begin{array}{c}\text { N } \\
\text { o }\end{array}$ & Factors & \multicolumn{1}{c|}{ Questionnaire Statement } \\
\hline 1 & $\begin{array}{l}\text { Business } \\
\text { process } \\
\text { change }\end{array}$ & $\begin{array}{l}\text { I have a positive belief that evaluating the readiness of } \\
\text { business process change is the critical factor in } \\
\text { supporting implementation ERP success for the } \\
\text { industry }\end{array}$ \\
\hline 2 & $\begin{array}{l}\text { Process } \\
\text { business } \\
\text { integration }\end{array}$ & $\begin{array}{l}\text { I have to be positive before implementing ERP, it is } \\
\text { necessary to standardize business processes taken } \\
\text { from the ERP system as an effective first step }\end{array}$ \\
\hline 3 & $\begin{array}{l}\text { Develop } \\
\text { ment of } \\
\text { business }\end{array}$ & $\begin{array}{l}\text { I have a positive belief that one way to manage } \\
\text { business processes is to be more effective for the } \\
\text { industry, so it is necessary to develop technological } \\
\text { innovations }\end{array}$ \\
\hline 4 & $\begin{array}{l}\text { Manage } \\
\text { ment } \\
\text { support }\end{array}$ & $\begin{array}{l}\text { I have positive beliefs that the support and active } \\
\text { involvement of management levels, ERP } \\
\text { implementation can be successful and timely. }\end{array}$ \\
\hline 5 & $\begin{array}{l}\text { Skill } \\
\text { project } \\
\text { team }\end{array}$ & $\begin{array}{l}\text { I have positive beliefs even though the ERP project is } \\
\text { coordinated by the IT team, but actually the ERP } \\
\text { project is not an IT project but a project management } \\
\text { that involves the management of an organization that } \\
\text { is committed and supports the change process }\end{array}$ \\
\hline
\end{tabular}


S.F. Wijaya et al. / Advances in Science, Technology and Engineering Systems Journal Vol. 5, No. 4, 733-740 (2020)

\begin{tabular}{|c|c|c|}
\hline 6 & $\begin{array}{l}\text { Training \& } \\
\text { education }\end{array}$ & $\begin{array}{l}\text { I have a positive belief that the intensive training } \\
\text { process is important to ensure users better understand } \\
\text { how ERP systems work effectively }\end{array}$ \\
\hline 7 & $\begin{array}{l}\text { Organiza } \\
\text { tion agile }\end{array}$ & $\begin{array}{l}\text { I have a positive belief, even though ERP } \\
\text { implementation has done a lot for the Industry and the } \\
\text { failure rate is still relatively high. However, an } \\
\text { evaluation of the implementation readiness can reduce } \\
\text { ERP implementation failure. }\end{array}$ \\
\hline 8 & $\begin{array}{l}\text { Communi } \\
\text { cation \& } \\
\text { collabora } \\
\text { tive }\end{array}$ & $\begin{array}{l}\text { I have a positive belief that effective and fast } \\
\text { communication of information and collaboration is } \\
\text { important in achieving successful ERP system } \\
\text { implementation }\end{array}$ \\
\hline 9 & $\begin{array}{l}\text { Project } \\
\text { manage } \\
\text { ment }\end{array}$ & $\begin{array}{l}\text { I have a positive belief that the skills of the project } \\
\text { team will provide feedback to provide solutions to } \\
\text { difficulties in ERP implementation. }\end{array}$ \\
\hline $\begin{array}{l}1 \\
0\end{array}$ & $\begin{array}{l}\text { Industry } \\
\text { characteris } \\
\text { tics }\end{array}$ & $\begin{array}{l}\text { I have a positive belief that one of the advantages of } \\
\text { the agile ERP model is to iterate at each stage to } \\
\text { ensure the stages of the ERP implementation process } \\
\text { run well. }\end{array}$ \\
\hline $\begin{array}{l}1 \\
1\end{array}$ & $\begin{array}{l}\text { Change } \\
\text { manage } \\
\text { ment }\end{array}$ & $\begin{array}{l}\text { I have a positive belief that the readiness to carry out } \\
\text { the stages of change management by following the } \\
\text { workings of the selected ERP system is one of the } \\
\text { critical factors in determining the success of ERP } \\
\text { implementation. }\end{array}$ \\
\hline $\begin{array}{l}1 \\
2\end{array}$ & $\begin{array}{l}\text { Strategic } \\
\text { planning }\end{array}$ & $\begin{array}{l}\text { I have a positive belief that the use of an ERP system } \\
\text { is an industrial adaptation requirement to improve } \\
\text { work efficiency, information integration, productivity, } \\
\text { and the organizational performance. }\end{array}$ \\
\hline $\begin{array}{l}1 \\
3\end{array}$ & $\begin{array}{l}\text { Organiza } \\
\text { tion culture }\end{array}$ & $\begin{array}{l}\text { I have a positive belief that corporate culture is a } \\
\text { cultural value that is rooted and difficult to change. } \\
\text { However, organizational readiness needs to make } \\
\text { changes that follow the business processes of the } \\
\text { selected ERP system }\end{array}$ \\
\hline $\begin{array}{l}1 \\
4\end{array}$ & $\begin{array}{l}\text { ERP } \\
\text { implementa } \\
\text { tion }\end{array}$ & $\begin{array}{l}\text { I have a positive belief that getting effective opinions } \\
\text { and feedback from users in every iteration is important } \\
\text { to ensure ERP implementation runs effectively }\end{array}$ \\
\hline $\begin{array}{l}1 \\
5\end{array}$ & $\begin{array}{l}\text { Agile } \\
\text { method }\end{array}$ & $\begin{array}{l}\text { I have a positive belief that increasing the success of } \\
\text { ERP implementation, so before implementing ERP for } \\
\text { an industry, it is necessary to assess the organization's } \\
\text { readiness for the change process }\end{array}$ \\
\hline $\begin{array}{l}1 \\
6\end{array}$ & $\begin{array}{l}\text { Technologi } \\
\text { cal }\end{array}$ & $\begin{array}{l}\text { I have a positive belief that one of the impacts of using } \\
\text { an ERP system is to get various information as needed } \\
\text { and to support decision making at the managerial level } \\
\text { of the organization }\end{array}$ \\
\hline $\begin{array}{l}1 \\
7\end{array}$ & $\begin{array}{l}\text { System } \\
\text { integration }\end{array}$ & $\begin{array}{l}\text { I have a positive belief that ERP is an integrated } \\
\text { system and needs technological innovation for optimal } \\
\text { use, so as to reduce duplication of work and increase } \\
\text { organizational productivity. }\end{array}$ \\
\hline $\begin{array}{l}1 \\
8\end{array}$ & $\begin{array}{l}\text { ERP } \\
\text { Systems }\end{array}$ & $\begin{array}{l}\text { I like the use of ERP systems in completing work, } \\
\text { because it will give effect to the work to be more } \\
\text { efficient and effective }\end{array}$ \\
\hline
\end{tabular}

\begin{tabular}{|c|c|c|c|c|c|c|c|c|c|c|c|c|c|c|c|}
\hline 3 & $\begin{array}{l}\text { Development } \\
\text { of business }\end{array}$ & 6 & & & & & 1 & 1 & & 3 & & 1 & & & \\
\hline 4 & $\begin{array}{l}\text { Management } \\
\text { support }\end{array}$ & $\begin{array}{l}7 \\
3 \\
\end{array}$ & & 2 & 1 & 1 & 2 & 5 & 1 & $\begin{array}{l}1 \\
4 \\
\end{array}$ & $\begin{array}{l}1 \\
2 \\
\end{array}$ & $\begin{array}{l}1 \\
6 \\
\end{array}$ & 9 & $\begin{array}{l}1 \\
0 \\
\end{array}$ & 0 \\
\hline 5 & $\begin{array}{l}\text { Skill project } \\
\text { team }\end{array}$ & $\begin{array}{l}4 \\
1 \\
\end{array}$ & & & 1 & & 2 & 1 & 8 & $\begin{array}{l}1 \\
0 \\
\end{array}$ & & $\begin{array}{l}1 \\
0 \\
\end{array}$ & 1 & 8 & \\
\hline 6 & $\begin{array}{l}\text { Training \& } \\
\text { education }\end{array}$ & $\begin{array}{l}1 \\
5 \\
\end{array}$ & 1 & 2 & 1 & 2 & 2 & & 1 & & 2 & 3 & & 1 & \\
\hline 7 & $\begin{array}{l}\text { Organization } \\
\text { agile }\end{array}$ & $\begin{array}{l}7 \\
8\end{array}$ & 4 & & & 1 & 1 & 5 & 2 & $\begin{array}{l}1 \\
7\end{array}$ & 4 & $\begin{array}{l}2 \\
9\end{array}$ & 8 & 3 & 4 \\
\hline 8 & $\begin{array}{l}\text { Communica } \\
\text { tion \& } \\
\text { collaborative }\end{array}$ & $\begin{array}{l}4 \\
0\end{array}$ & 1 & & 5 & 3 & 2 & 3 & & 9 & 2 & $\begin{array}{l}1 \\
0\end{array}$ & 4 & 1 & \\
\hline 9 & $\begin{array}{l}\text { Project } \\
\text { management }\end{array}$ & $\begin{array}{l}1 \\
6 \\
\end{array}$ & & & & & & & 1 & 4 & 1 & 4 & 3 & 3 & \\
\hline $\begin{array}{l}1 \\
0 \\
\end{array}$ & $\begin{array}{l}\text { Industry } \\
\text { characteristics }\end{array}$ & $\begin{array}{l}1 \\
4 \\
\end{array}$ & & & 1 & 1 & & 3 & 3 & 2 & & 3 & 1 & & \\
\hline $\begin{array}{l}1 \\
1\end{array}$ & $\begin{array}{l}\text { Change } \\
\text { management }\end{array}$ & $\begin{array}{l}1 \\
0\end{array}$ & & 1 & & & 1 & & & 2 & 1 & 5 & & & \\
\hline $\begin{array}{l}1 \\
2 \\
\end{array}$ & $\begin{array}{l}\text { Strategic } \\
\text { planning }\end{array}$ & 8 & & 1 & & & 1 & 1 & & & & 4 & & 1 & \\
\hline $\begin{array}{l}1 \\
3 \\
\end{array}$ & $\begin{array}{l}\text { Organization } \\
\text { culture }\end{array}$ & 6 & & 2 & & & & & & & 2 & & & & 2 \\
\hline $\begin{array}{l}1 \\
4\end{array}$ & $\begin{array}{l}\text { ERP } \\
\text { implementa } \\
\text { tion }\end{array}$ & $\begin{array}{l}1 \\
5\end{array}$ & & & & & 1 & 1 & & & 3 & 1 & 5 & 1 & 3 \\
\hline $\begin{array}{l}1 \\
5\end{array}$ & Agile method & $\begin{array}{l}1 \\
9\end{array}$ & 2 & & & & 1 & 2 & & & 8 & 2 & & 2 & 2 \\
\hline $\begin{array}{l}1 \\
6 \\
\end{array}$ & Technological & $\begin{array}{l}1 \\
0\end{array}$ & & & & 1 & & & 3 & 2 & & 1 & 2 & 1 & \\
\hline $\begin{array}{l}1 \\
7\end{array}$ & $\begin{array}{l}\begin{array}{l}\text { System } \\
\text { integration }\end{array} \\
\end{array}$ & $\begin{array}{l}1 \\
0 \\
\end{array}$ & 1 & & & & & 1 & & & 5 & & & 3 & \\
\hline $\begin{array}{l}1 \\
8 \\
\end{array}$ & ERP systems & $\begin{array}{l}1 \\
0\end{array}$ & & & & & 1 & 1 & 4 & & 3 & & 1 & & \\
\hline
\end{tabular}

Based on the calculated processing follow the stages of weighting the TOPSIS method are as follows:

1. Normalized weighted matrix is 31710

2. Weighted normalized matrix by multiplying the normalized matrix with the weighting value $\min$ is 0,61 and $\max$ is 1,30

3. Matrix for positive is 0,47 and matrix for negative is 1,51

4. Value of each alternative solution with a positive ideal solution matrix is 2,76 and a negative ideal solution matrix is 5,08

5. Preferences value is 11,67

6. Ranking the value of each factors are weights sub-factors shown in the Table 9.

The summary result of data questionnaire processing by TOPSIS approach that rank the factors for each dimension that the processes dimension is $17 \%$, people dimension is $15 \%$, organizational dimension is $40 \%$, and the technology dimension is $28 \%$. Thus, the organizational readiness is the most important also. The results weight analysis of TOPSIS approach is shown in the Table 9.

Table 9: The result weight analysis of TOPSIS dimension is $28 \%$, organizational dimension is $37 \%$, and the technology dimension is $14 \%$. Thus, the organizational readiness is the most important. The results of FGD by NVivo application is shown in the Table 8 .

Table 8: The result indicators of managing data analysis

\begin{tabular}{|c|c|c|c|c|c|c|c|c|c|c|c|c|c|c|c|}
\hline & & & \multicolumn{13}{|c|}{ Respondent } \\
\hline $\begin{array}{l}\mathrm{N} \\
\mathrm{o}\end{array}$ & Factors & \# & 1 & 2 & 3 & 4 & 5 & 6 & 7 & 8 & 9 & 1 & 1 & 1 & 1 \\
\hline 1 & $\begin{array}{l}\text { Business } \\
\text { process } \\
\text { change }\end{array}$ & $\begin{array}{l}6 \\
6\end{array}$ & & 5 & 1 & 6 & 1 & & 1 & $\begin{array}{l}1 \\
3\end{array}$ & $\begin{array}{l}1 \\
2\end{array}$ & $\begin{array}{l}1 \\
7\end{array}$ & 6 & 4 & \\
\hline 2 & $\begin{array}{l}\text { Process } \\
\text { business } \\
\text { integration }\end{array}$ & $\begin{array}{l}2 \\
2\end{array}$ & 1 & 2 & 1 & 3 & 1 & & & 2 & 7 & 2 & 2 & 1 & \\
\hline
\end{tabular}

\begin{tabular}{|c|c|c|c|c|c|c|c|c|c|c|}
\hline No & Factors & $\begin{array}{l}\text { Squ } \\
\text { ared }\end{array}$ & $\begin{array}{l}\mathrm{M} \\
\text { in }\end{array}$ & $\begin{array}{l}\mathrm{M} \\
\mathrm{ax}\end{array}$ & $\begin{array}{c}(-) \\
\text { addi } \\
\text { tion }\end{array}$ & $\begin{array}{c}(+) \\
\text { addi } \\
\text { tion }\end{array}$ & $\begin{array}{c}(- \\
\text { (- } \\
\text { or } \\
\mathrm{e}\end{array}$ & $\begin{array}{l}(+) \\
\mathrm{sc} \\
\text { or } \\
\mathrm{e}\end{array}$ & $\begin{array}{c}\text { Pre } \\
\text { fe- } \\
\text { ren } \\
\text { ce } \\
\text { sco } \\
\text { re }\end{array}$ & $\begin{array}{l}\text { Fi } \\
\text { nal } \\
\text { wei } \\
\text { ghts }\end{array}$ \\
\hline 1 & $\begin{array}{l}\text { Business } \\
\text { process } \\
\text { change }\end{array}$ & $\begin{array}{l}175 \\
3\end{array}$ & $\begin{array}{l}0, \\
03\end{array}$ & $\begin{array}{l}0, \\
07\end{array}$ & 0,09 & 0,02 & $\begin{array}{l}0, \\
30\end{array}$ & $\begin{array}{l}0, \\
14\end{array}$ & $\begin{array}{l}0,6 \\
8 \\
\end{array}$ & $\begin{array}{l}34 \\
\%\end{array}$ \\
\hline 2 & $\begin{array}{l}\text { Process } \\
\text { business } \\
\text { integra } \\
\text { tion }\end{array}$ & $\begin{array}{l}183 \\
8\end{array}$ & $\begin{array}{l}0, \\
03\end{array}$ & $\begin{array}{l}0, \\
08\end{array}$ & 0,12 & 0,02 & $\begin{array}{l}0, \\
35\end{array}$ & $\begin{array}{l}0, \\
16\end{array}$ & $\begin{array}{l}0,7 \\
0\end{array}$ & $\begin{array}{l}34 \\
\%\end{array}$ \\
\hline
\end{tabular}


S.F. Wijaya et al. / Advances in Science, Technology and Engineering Systems Journal Vol. 5, No. 4, 733-740 (2020)

\begin{tabular}{|c|c|c|c|c|c|c|c|c|c|c|}
\hline 3 & $\begin{array}{l}\text { Develop } \\
\text { ment of } \\
\text { business }\end{array}$ & $\begin{array}{l}166 \\
7\end{array}$ & $\begin{array}{l}0, \\
03\end{array}$ & $\begin{array}{l}0, \\
07\end{array}$ & 0,09 & 0,02 & $\begin{array}{l}0, \\
29\end{array}$ & $\begin{array}{l}0, \\
15\end{array}$ & $\begin{array}{l}0,6 \\
6\end{array}$ & $\begin{array}{l}32 \\
\%\end{array}$ \\
\hline 4 & $\begin{array}{l}\text { Manage } \\
\text { ment } \\
\text { support }\end{array}$ & $\begin{array}{l}174 \\
4\end{array}$ & $\begin{array}{l}0, \\
05\end{array}$ & $\begin{array}{l}0, \\
08 \\
\end{array}$ & 0,04 & 0,02 & $\begin{array}{l}0, \\
19 \\
\end{array}$ & $\begin{array}{l}0, \\
15 \\
\end{array}$ & $\begin{array}{l}0,5 \\
7\end{array}$ & $\begin{array}{l}33 \\
\%\end{array}$ \\
\hline 5 & $\begin{array}{l}\text { Project } \\
\text { team }\end{array}$ & $\begin{array}{l}143 \\
3\end{array}$ & $\begin{array}{l}0, \\
04\end{array}$ & $\begin{array}{l}0, \\
11\end{array}$ & 0,18 & 0,13 & $\begin{array}{l}0, \\
42\end{array}$ & $\begin{array}{l}0, \\
35\end{array}$ & $\begin{array}{l}0,5 \\
4\end{array}$ & $\begin{array}{l}32 \\
\%\end{array}$ \\
\hline 6 & $\begin{array}{l}\text { Training } \\
\& \\
\text { education }\end{array}$ & $\begin{array}{l}183 \\
6 \\
\end{array}$ & $\begin{array}{l}0, \\
04 \\
\end{array}$ & $\begin{array}{l}0, \\
07 \\
\end{array}$ & 0,04 & 0,02 & $\begin{array}{l}0, \\
20 \\
\end{array}$ & $\begin{array}{l}0, \\
13 \\
\end{array}$ & $\begin{array}{l}0,6 \\
0 \\
\end{array}$ & $\begin{array}{l}35 \\
\%\end{array}$ \\
\hline 7 & $\begin{array}{l}\text { Organiza } \\
\text { tion } \\
\text { agility }\end{array}$ & $\begin{array}{l}176 \\
0\end{array}$ & $\begin{array}{l}0, \\
03 \\
\end{array}$ & $\begin{array}{l}0, \\
07 \\
\end{array}$ & 0,10 & 0,02 & $\begin{array}{l}0, \\
31 \\
\end{array}$ & $\begin{array}{l}0, \\
14 \\
\end{array}$ & $\begin{array}{l}0,6 \\
8 \\
\end{array}$ & $\begin{array}{l}15 \\
\%\end{array}$ \\
\hline 8 & $\begin{array}{l}\text { Commun } \\
\text { ication \& } \\
\text { collabora } \\
\text { tive }\end{array}$ & $\begin{array}{l}179 \\
7\end{array}$ & $\begin{array}{l}0, \\
04\end{array}$ & $\begin{array}{l}0, \\
07\end{array}$ & 0,03 & 0,02 & $\begin{array}{l}0, \\
18\end{array}$ & $\begin{array}{l}0, \\
13\end{array}$ & $\begin{array}{l}0,5 \\
8\end{array}$ & $\begin{array}{l}12 \\
\%\end{array}$ \\
\hline 9 & $\begin{array}{l}\text { Project } \\
\text { manage } \\
\text { ment }\end{array}$ & $\begin{array}{l}186 \\
5 \\
\end{array}$ & $\begin{array}{l}0, \\
03 \\
\end{array}$ & $\begin{array}{l}0, \\
07 \\
\end{array}$ & 0,10 & 0,02 & $\begin{array}{l}0, \\
31 \\
\end{array}$ & $\begin{array}{l}0, \\
12 \\
\end{array}$ & $\begin{array}{l}0,7 \\
2 \\
\end{array}$ & $\begin{array}{l}15 \\
\%\end{array}$ \\
\hline 10 & $\begin{array}{l}\text { Change } \\
\text { manage } \\
\text { ment }\end{array}$ & $\begin{array}{l}175 \\
1\end{array}$ & $\begin{array}{l}0, \\
03\end{array}$ & $\begin{array}{l}0, \\
07\end{array}$ & 0,10 & 0,02 & $\begin{array}{l}0, \\
32\end{array}$ & $\begin{array}{l}0, \\
15\end{array}$ & $\begin{array}{l}0,6 \\
8\end{array}$ & $\begin{array}{l}15 \\
\%\end{array}$ \\
\hline 11 & $\begin{array}{l}\text { Industry } \\
\text { characte } \\
\text { ristics }\end{array}$ & $\begin{array}{l}167 \\
4\end{array}$ & $\begin{array}{l}0, \\
03 \\
\end{array}$ & $\begin{array}{l}0, \\
07 \\
\end{array}$ & 0,09 & 0,03 & $\begin{array}{l}0, \\
30 \\
\end{array}$ & $\begin{array}{l}0, \\
16 \\
\end{array}$ & $\begin{array}{l}0,6 \\
6 \\
\end{array}$ & $\begin{array}{l}14 \\
\%\end{array}$ \\
\hline 12 & $\begin{array}{l}\text { Strategic } \\
\text { planning }\end{array}$ & $\begin{array}{l}174 \\
7\end{array}$ & $\begin{array}{l}0, \\
03\end{array}$ & $\begin{array}{l}0, \\
06\end{array}$ & 0,08 & 0,09 & $\begin{array}{l}0, \\
29\end{array}$ & $\begin{array}{l}0, \\
13\end{array}$ & $\begin{array}{l}0,6 \\
9\end{array}$ & $\begin{array}{l}15 \\
\%\end{array}$ \\
\hline 13 & $\begin{array}{l}\text { Organiza } \\
\text { tion } \\
\text { culture }\end{array}$ & $\begin{array}{l}168 \\
1 \\
\end{array}$ & $\begin{array}{l}0, \\
03 \\
\end{array}$ & $\begin{array}{l}0, \\
08 \\
\end{array}$ & 0,11 & 0,03 & $\begin{array}{l}0, \\
33 \\
\end{array}$ & $\begin{array}{l}0, \\
17 \\
\end{array}$ & $\begin{array}{l}0,6 \\
6 \\
\end{array}$ & $\begin{array}{l}14 \\
\%\end{array}$ \\
\hline 14 & $\begin{array}{l}\text { ERP } \\
\text { implem } \\
\text { entation }\end{array}$ & $\begin{array}{l}178 \\
6\end{array}$ & $\begin{array}{l}0, \\
04 \\
\end{array}$ & $\begin{array}{l}0, \\
07\end{array}$ & 0,03 & 0,09 & $\begin{array}{l}0, \\
18 \\
\end{array}$ & $\begin{array}{l}0, \\
13 \\
\end{array}$ & $\begin{array}{l}0,5 \\
8 \\
\end{array}$ & $\begin{array}{l}18 \\
\%\end{array}$ \\
\hline 15 & $\begin{array}{l}\text { Agile } \\
\text { method }\end{array}$ & $\begin{array}{l}173 \\
8 \\
\end{array}$ & $\begin{array}{l}0, \\
03 \\
\end{array}$ & $\begin{array}{l}0, \\
08 \\
\end{array}$ & 0,14 & 0,03 & $\begin{array}{l}0, \\
37 \\
\end{array}$ & $\begin{array}{l}0, \\
17 \\
\end{array}$ & $\begin{array}{l}0,6 \\
8 \\
\end{array}$ & $\begin{array}{l}21 \\
\%\end{array}$ \\
\hline 16 & $\begin{array}{l}\text { Technolo } \\
\text { gical }\end{array}$ & $\begin{array}{l}193 \\
8\end{array}$ & $\begin{array}{l}0, \\
05\end{array}$ & $\begin{array}{l}0, \\
08\end{array}$ & 0,05 & 0,02 & $\begin{array}{l}0, \\
23\end{array}$ & $\begin{array}{l}0, \\
12\end{array}$ & $\begin{array}{l}0,6 \\
5\end{array}$ & $\begin{array}{l}20 \\
\%\end{array}$ \\
\hline 17 & $\begin{array}{l}\text { System } \\
\text { integra } \\
\text { tion }\end{array}$ & $\begin{array}{l}200 \\
8\end{array}$ & $\begin{array}{l}0, \\
04 \\
\end{array}$ & $\begin{array}{l}0, \\
07\end{array}$ & 0,05 & 0,01 & $\begin{array}{l}0, \\
22\end{array}$ & $\begin{array}{l}0, \\
11\end{array}$ & $\begin{array}{l}0,6 \\
8\end{array}$ & $\begin{array}{l}21 \\
\%\end{array}$ \\
\hline 18 & $\begin{array}{l}\text { ERP } \\
\text { systems }\end{array}$ & $\begin{array}{l}169 \\
4\end{array}$ & $\begin{array}{l}0, \\
03\end{array}$ & $\begin{array}{l}0, \\
07\end{array}$ & 0,09 & 0,02 & $\begin{array}{l}0, \\
30 \\
\end{array}$ & $\begin{array}{l}0, \\
15 \\
\end{array}$ & $\begin{array}{l}0,6 \\
6 \\
\end{array}$ & $\begin{array}{l}20 \\
\%\end{array}$ \\
\hline & & $\begin{array}{l}317 \\
10\end{array}$ & $\begin{array}{l}0, \\
61 \\
\end{array}$ & $\begin{array}{l}1, \\
30\end{array}$ & 1,51 & 0,47 & $\begin{array}{l}5, \\
08\end{array}$ & $\begin{array}{l}2, \\
76\end{array}$ & $\begin{array}{l}11, \\
67\end{array}$ & $\begin{array}{l}400 \\
\%\end{array}$ \\
\hline
\end{tabular}

reason, the authors propose the ERP readiness assessment framework in the industry that can be shown in Figure 1.

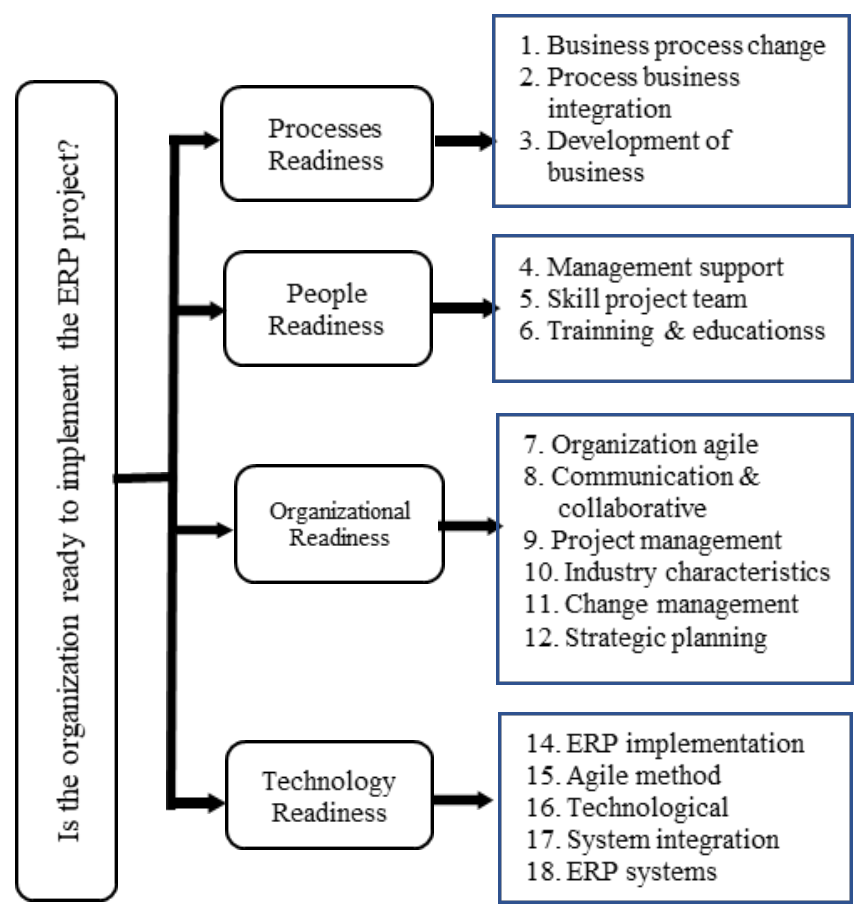

Figure 1: Framework hierarchy of ERP readiness assessment

\section{Conclusion}

The focus of integrated information systems is to provide solutions by aligning information technology and business processes to meet business needs. The readiness assessment is considered as a fundamental factor in order to increase agility in the industry before the organization's management decides to implement the ERP project. The agile method approach is to be considered as one of the suitable methods for assessing organizational readiness to support organizational activities with rapid adaptation and simplification of processes with focusing on quality and time. The agile factors activities such as flexibility, speed, responsiveness, competency, accountability, integration.

The result of this research indicate that the readiness factors are mapped with agile factors can contribute significantly in order to improve the organization agility. Before the organization decision to implement the ERP project, it is necessary to consider the readiness factors of the main components such as processes, people, organizational, and technology. The readiness assessment model for ERP implementation as one solution to reduce the complexity of ERP implementation can be considered. The authors realize that the research has limitations in analyzing the results of data processing and case study. Therefore, a challenge for future research is how effective to transfer this method practically and necessary to conduct further research as validation agile factors and maturity in ERP readiness assessment with case studies in other industries that can be used as benchmarks for the agile ERP readiness assessment framework. 


\section{References}

[1] Z. Zhang, et al., "Framework of ERP systems implementation success in China: An empirical study". International Journal of Production Economics, 98(1), 56-8,. 2005. DOI: 10.1016/j.ijpe.2004.09.004.

[2] J. Razmi,, R. Ghodsi, M.S. Sangari, "A fuzzy ANP model to assess the state of organizational readiness for ERP implementation". In 4th International Conference on Information and Automation for Sustainability. 13. 2009. DOI: 10.1109/ICIAFS.2008.4783989

[3] R.O. Yusuff, J.A. Sonibare, “Characterization of textile industries' effluents in Kaduna, Nigeria and pollution implications". Global Nest: Int. J, 6(3), 212-221, 2004.

[4] R. Avazpour, E. Ebrahimi, M.R. Fathi, "Prioritizing agility enablers based on agility attributes using fuzzy prioritization method and similarity-based approach". International Journal of Economy, Management and Social Sciences, 3(1), 143-153, 2014.

[5] S. Ahmadi, E. Papageorgiou, C.H. Yeh, R. Martin, "Managing readinessrelevant activities for the organizational dimension of ERP implementation". Computers in Industry, 68, 89-104. 2015.

[6] H.N. Gandhi, "Analisis Tingkat Kematangan Proses Bisnis Perusahaan Garmen Kelas Menengah". (Doctoral dissertation, Institut Teknologi Sepuluh Nopember). repository.its.ac.id/id/eprint/42365. 2017.

[7] D. Soysa, J. Nanayakkara, "Readiness for ERP implementation in an organization: Development of an assessment model". International Conference on Information and Automation (pp.27-32). IEEE. 2.2006. DOI: 10.1109/ICINFA.2006.374147

[8] P. Hanafizadeh, A.Z. Ravasan, "A McKinsey 7S model-based framework for ERP readiness assessment". International Journal of Enterprise Information Systems (IJEIS), 7(4), 23-63.2011.

[9] M. Kirmizi, B. Kocaoglu, "The key for success in enterprise information systems projects: development of a novel ERP readiness assessment method and a case study". Enterprise Information Systems, 14(1), 1-37.2020. DOI: 10.1080/17517575.2019.1686656

[10] L. Raymond, S. Rivard, D. Jutras, "Evaluating readiness for ERP adoption in manufacturing SMEs". International Journal of Enterprise Information Systems (IJEIS), 2(4), 1-17.2006. DOI: 10.4018/jeis.2006100101

[11] S. Shiri, A. Anvari, H. Soltani, "Identifying and prioritizing of readiness factors for implementing ERP based on agility (extension of McKinsey $7 \mathrm{~S}$ model)". European Online Journal of Natural and Social Sciences: Proceedings, 4(1), 56, 2015.

[12] A. Liberati, D.G. Altman, J. Tetzlaff, C. Mulrow. "The PRISMA statement for reporting systematic reviews and metaanalyses of studies that evaluate health care interventions: explanation and elaboration. J. Clin.Epidemiol". 62(10). 2009. DOI: 10.7326/0003-4819-151-4-200908180-00136

[13] H.J. Leavitt, "Applied Organizational Change in Industry, Structural, Technological and Humanistic Approaches. Handbook of organizations. 1965.

[14] L.M. Liao, C.J. Huang, X.Y. Lin, “Applying Project Management Perspective for ERP Implementation: A Case Study". Proceedings of Engineering and Technology Innovation, 8, 40-45.2018.

[15] A.N. Hidayanto, M.A. Hasibuan, P.W. Handayani, Y.G. Sucahyo, "Framework for Measuring ERP Implementation Readiness in Small and Medium Enterprise (SME): A Case Study in Software Developer Company". JCP, 8(7), 1777-1782. 2013.

[16] A. Kraljic, T. Kraljic, "Agile Software Engineering Practices and ERP: Is a sprint too fast for ERP Implementation?". 2017.

[17] Campanelli \& Parreiras. "Agile methods tailoring-A systematic literature review". Journal of Systems and Software, 110,85-100. 2015. DOI: /10.1016/j.jss.2015.08.035

[18] M. Mariouli, J. Laassiri, "Applying Agile Procedure Model to Improve ERP Systems Implementation Strategy". In International Conference Europe Middle East \& North Africa Information Systems and Technologies to Support Learning (pp.471-481). Springer, Cham. 111.2019. DOI: 10.1007/978-3-030-03577-8_52

[19] J. Ram, D. Corkindale, M.L. Wu, "Examining the role of organizational readiness in ERP project delivery". Journal of Computer Information Systems, 55(2), 29-39. 2015. DOI: 10.1080/08874417.2015.11645754

[20] J.J.A. Baig et al., "Evaluation of agile methods for quality assurance and quality control in ERP implementation". In Intelligent Computing and Information Systems (ICICIS), Eighth International Conference, 252-257, 2017. DOI: 10.1109/INTELCIS.2017.8260055

[21] P.C. Hui et al., "Enterprise resource planning systems for the textiles and clothing industry". Innovative Quick Response Programs in Logistics
Supply Chain Management (pp. 279-295). Springer Berlin Heidelberg. 28.2010. DOI: 10.1007/978-3-642-04313-0_14

[22] A.A. Fetouh et al., "Applying Agile Approach in ERP Implementation". IJCSNS, 11(8). 2011.

[23] MI.M. Nofal et al., "Conceptual model of enterprise resource planning and business intelligence systems usage". International Journal of Business Information Systems, 21(2), 178-194.2016.

[24] G. Lee, W. Xia, "Toward agile: an integrated analysis of quantitative and qualitative field data on software development agility". MIS Quarterly, 34(1), 87-114. 2010. DOI: 10.2307/20721416

[25] J. Azar et al., "Using the agile implementation model to reduce central lineassociated bloodstream infections". American journal of infection control. 47(1). 2018 DOI: $10.1016 /$ j.ajic.2018.07.008

[26] B. Sherehiy et al., "A review of enterprise agility: Concepts, frameworks, and attributes". International Journal of industrial ergonomics, 37(5), 445460. 2007. DOI: $10.1016 /$ j.ergon.2007.01.007

[27] M. Bruce et al., "Lean or agile: a solution for supply chain management in the textiles and clothing industry?". International journal of operations \& production management, 24(2), 151-170. 2004. DOI: $10.1108 / 01443570410514867$

[28] R. Rambola et al., "An Effective Synchronization of ERP in Textile Industries". Second International Conference on Electronics, Communication and Aerospace Technology (ICECA), 969-973, 2018. DOI: 10.1109/ICECA.2018.8474686

[29] C.L. Hwang, K. Yoon, "Methods for multiple attribute decision making". In Multiple attribute decision making (pp.58-191). Springer, Berlin, Heidelberg. 186.1981. DOI:10.1007/978-3-642-48318-9_3. 